\title{
SUPOPTAGE COLLEGE
}

Portage College (formerly Alberta Vocational College - Lac La Biche). The Forest Technician program is a one year certificate program designed to prepare personnel in the practi$\mathrm{cal}$ and technical skills needed to work in the forest industry. The program consists of classroom lectures and field training using current industry practices. The program stays current through close liaison with industry and government and receives input on curriculum and field activities from a Forestry Advisory Committee. Subject areas include: Communications, Equipment and Safety, Silviculture, Fitness, Outdoor Skills, Work Experience, Forest Protection, Forest Management, Forest Measurements, Harvesting, and Wood Utilization. Employment opportunities exist within all areas of the forest sector. Graduates have worked with forestry consultants, forestry companies, and with the Department of Environmental Protection, Lands and Forest Services Branch. Graduates have also worked as independent forestry contractors, and have branched off into other industries that are directly associated with forestry land management. For further information contact: Admissions, Portage College, P.O. Box 417, Lac La Biche, Alberta TOA 2C0, Phone (780) 6235551 or toll free (Alberta only) 310-0000 then enter 623-5551.

ENVIRONMENTAL TRAINING CENTRE, Hinton, Alberta. The Environmental Training Centre (ETC) is an in-service training centre operated by Alberta Environment. The Centre offers a number of natural resource management courses including a unique and highly-advanced fire control program which uses laserdisc technology for fire simulations. Also an array of Forest Management programs including AAFMI Modules. The Centre houses the headquarters of the Foothills Model Forest and the Wildland Fires Operations Research Centre for FERIC. The second year of the Forest Technology program of the Northern Alberta Institute of Technology is presently taught at the Centre. Members of the forest industry and other cooperating agencies are welcome to register to attend any ETC course. For further information, contact Director, Environmental Training Centre, 1176 Switzer Drive, Hinton, Alberta T7V 1V3. Phone: 780-865-8200. Fax: 780865-8266. E-mail: envtrain@env.gov.ab.ca

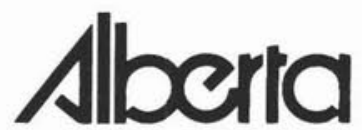

ENVTFONAGEAT

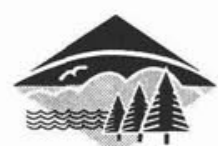

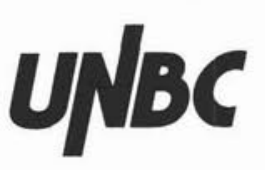

grams. MSc and PhD degree programs Studies are also available. The undergraduate Forestry major is accredited by the Canadian Forestry Accreditation Board. The 4-year program of study includes a number of courses in common with the Wildlife and Fisheries major in such areas as forest biology, integrated resource management, resource planning, issues and ethics, and others. The intent is to provide a broad interdisciplinary foundation for specialization in the chosen major. Cooperative education opportunities are available. UNBC's Prince George campus is strategically located in the center of the province, amidst the province's major forest resource base, and thus has access to a wide range of forest types. The university is involved in a number of model and demonstration forests and has two research forests. We train the managers and scientists needed to effectively meet the demands for services and products from natural resources and still maintain a quality environment. The wise and sustainable use of our forest, fisheries, recreational and wildlife resources is a potent driver of our educational mission. Supported by programs in Resource Recreation/Tourism, Environmental Studies, Geography and Biology, the Forestry faculty conducts its research on issues that affect northern British Columbia and similar regions elsewhere in the world. Please direct enquiries to the Chair of the program, 3333 University Way, Prince George, BC, V2N 4Z9. Telephone: (250) 960-6664, Fax: (250) 960-5539.

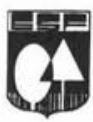

L'École de sciences forestières (ÉSF) de l'Université de Moncton, Campus d'Edmundston, offre un programme de baccalauréat et de maîtrise en sciences forestières. Le programme de baccalauréat de cinq ans permet aux étudiants et étudiantes d'acquérir des connaissances sur les aspects environnementaux, biologiques, socio-économiques et technologiques reliées à la foresterie. II vise aussi à leur inculquer une vision de l'aménagement intégré des ressources et du développement durable des forêts. Il est également offert en régime coopératif, une alternance de sessions d'études et de stages rémunérés au sein de diverses organisations canadiennes. Les diplômés et diplômées sont admissibles aux différentes corporations professionnelles canadiennes. L'admission au programme de baccalauréat peut s'effectuer dès la fin des études secondaires. Ceux et celles possédant une formation collégiale peuvent obtenir des équivalences de cours. La maîtrise ès sciences forestières comprend une thèse et quatre cours dont deux sont obligatoires. Plusieurs projets de thèse sont de nature appliquée et traitent de problématiques dans les thèmes suivants : écologie, dynamique et aménagement des écosystèmes forestiers, sylviculture, habitat faunique, géomatique environnementale, foresterie sociale et économique, aménagement des bassins versants, agroforesterie. L'ÉSF gère une Forêt expérimentale de 830 ha située à $40 \mathrm{~km}$ d'Edmundston, utilisée pour les travaux pratiques des classes, la recherche et les activités récréatives et éducationnelles. Pour plus de renseignements:École de sciences forestières, 165, boul. Hébert, Edmundston, N.-B., E3V 2S8. Tél.: 1-800-561-9064 ou (506)737-5068. Téléc.: (506)737-5373. Courriel : clajoie@cusim.ca

Site : www.cusIm.ca/ESF

\section{Lakehead}

The Faculty of Forestry and the Forest Environment offers the following programs: Honours Bachelor of Science in Forestry (H.B.Sc.F.), Honours Bachelor of Environmental Studies (Forest Conservation) (H.B.E.S.), Bachelor of Environmental Studies (Forest Conservation) (B.E.S.), Master of Science in Forestry (M.Sc.F.) and Master of Forestry (M.F.). The H.B.Sc.F. provides the academic requirements for membership in the Professional Forester Associations across Canada. The variety of professional, science and elective courses completed over four years prepares graduates for a wide range of resource management positions. This program is also available as a five-year Cooperative Education Option. The HBES/BES curricula combine a core of forestry courses with a broad range of science and arts electives. In this way, the student develops specialization in a complimentary area while becoming fully cognizant of forest resource management techniques and challenges. Diploma graduates from forestry and allied disciplines are encouraged to consider application to any of our undergraduate programs. Advanced standing requirements are published in the university calendar and evaluations are completed upon receipt of an application. The M.Sc.F. program is research oriented and requires a thesis. The M.F. emphasizes professional studies and, in particular, advanced skills in forest decision making. Students with undergraduate degrees in allied disciplines are encouraged to apply. Further information may be obtained from: Faculty of Forestry and the Forest Environment, Lakehead University, 955 Oliver Road, Thunder Bay, ON, P7B 5E1, by email: sandy.dunning@lakeheadu.ca or by visiting our website: http://www.lakeheadu.ca/ forwww/forestry.html.

University

of

Alberta
THE FACULTY OF AGRICULTURE, FORESTRY AND HOME ECONOMICS offers eight undergraduate Bachelor of Science programs, including degrees in Forestry, Forest Business Management, and Environmental and Conservation Sciences. In these programs, students may major in forest management; forest business management; conservation biology; environmental economics and policy; human dimensions of environmental management; or land reclamation. The Forestry and Forest Business Management degrees are designed to meet the CFAB standards for professional forestry registration. The Faculty prides itself on being a leader in the education and training of resource managers from a holistic and integrated perspective. For more information call the Office of the Dean at (780) $492-4933$ or $1-800$ 804-6417 (in Western Canada) or visit the web site at www.afhe.ualberta.ca. 


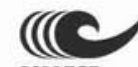

COLLEGE

OF THE

NORTH

ATLANTIC
COLLEGE OF THE NORTH ATLANTIC, Corner Brook Campus, P.O. Box 822, Corner Brook, NF A2H $6 \mathrm{H} 6$.

The College of the North Atlantic offers a group of programs in the natural resources technology field. The two-year Forest Resources Technician diploma program shares many common courses with the Fish and Wildlife Technician program. The Forest Resources program includes a balance of class, lab and crew fieldwork experiences in forest utilization, protection, improvement, and management. Students are exposed throughout the program to the use of computer technology in general and to GIS software in particular. A wide range of specific technical topics is included with the trend towards integrated management of our natural resources. The Forest Resources program is internationally recognized by the Society of American Foresters, and nationally accredited by the Canadian Council of Technicians and Technologists. For more information, call (709) 637-8517; fax (709)637-8645; or write to; Forest Resources Technician program, Corner Brook Campus, College of the North Atlantic, P.O. Box 822, Corner Brook, NF A2H $6 \mathrm{H} 6$

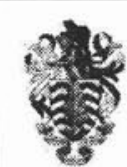

The University of Toronto. The Faculty of Forestry is primarily a graduate faculty that offers Ph.D. and M.Sc.F. research programs, focused primarily on forest conservation. Most fields of forestry are represented in graduate thesis research, particularly forest ecology, wildlife conservation, silviculture, forest soils and tree nutrition, soil erosion and land reclamation, fire management systems, forest entomology, tree physiology, community forestry, forest economics, wood science, fibre science, wood and composite product development, forest certification and urban forestry. The Faculty also offers a 16-month Master of Forest Conservation (M.F.C.) program, focused strongly on global forest conservation with a 3 month practical internship and an international field course, and a collaborative Master of Wood Engineering (M.Sc.) program with the Faculty of Applied Science and Engineering, with industrial internships. The Faculty also participa studies and environmental toxicology with the Institute for Environmental Studies. In collaboration with the Faculty of Arts and Science, students may take a specialist program in forest conservation leading to either an Hon.B.Sc. or an Hon.B.A. degree. The B.Sc. (Forest Conservation Science) focuses primarily on forest ecology while the B.A. (Forest Conservation) focuses on communal forest management and the development of forest policy.

The Faculty welcomes students from diverse backgrounds particularly forestry, ecology, environmental sciences, international development studies, biology, botany, geography, zoology, agriculture, engineering, mathematics and computer science and social sciences. The Faculty shares the Earth Sciences Centre with Geology, Botany and the Institute for Environmental Studies, and has well-equipped laboratories and computer facilities. The Faculty participates in the 400 ha Joker's Hill environmental research forest on the Oak Ridges Moraine, and also has a research collaborative agreement with Haliburton Forest and Wild Life Reserve Limited, with a 25,000 ha forest close to Algonquin Park.

Direct enquiries to: Faculty of Forestry, University of Toronto, 33 Willcocks St., Toronto, Ontario M5S 3B3; (Phone) 416-978-6152; (Fax) 416-978-3834; (Email) gradprog@forestry.ca; (WWW) http:wWw.forestry.utoronto.ca

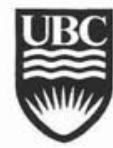

THE UNIVERSITY OF BRITISH COLUMBIA. The Faculty of Forestry offers four-year degree programs in Forest Resources Management, Forest Operations, Forest Sciences, Wood Products Processing, and Natural Resources Conservation. The Management and the Operations programs are fully accredited by the Canadian Forestry Accreditation Board. Graduates of these two programs are eligible for registration as Forestersin-Training in the Association of B.C. Professional Foresters. Each degree program has required courses designed to enhance knowledge as well as increase technical skills. The Faculty also offers programs leading to MSc, MASc, MF, and PhD degrees in most fields of Forestry and Wood Science. The UBC campus is surrounded by a large forested regional park which is frequently used as an outdoor classroom for forestry labs. In addition, the Faculty of Forestry maintains two research forests: the Malcolm Knapp Research Forest in Maple Ridge and the Alex Fraser Research Forest near Williams Lake. The Faculty of Forestry supports two specialized research centres: the Centre for Applied Conservation Biology and the Centre for Advanced Wood Processing

Direct enquiries to the Faculty of Forestry, Forest Sciences Centre, 2005-2424 Main Mall, Vancouver, BC V6T 1Z4. Telephone (604) 822-2727. Fax (604) 822-8645. E-mail: forrecep @ interchg.ubc.ca. Additional information is available on the Faculty of Forestry Home Page http://www.forestry.ubc.ca.

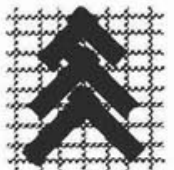

FACULTY OF FORESTRY \& ENVIRONMENTAL MANAGEMENT, University of New Brunswick, Fredericton, NB. Degree programs in Forestry (BSCF) and Forest Engineering (BScFE) after grade XII or Quebec High School Leaving Examinations. The BsScF program includes a blend of biophysical, social, and management sciences; electives can lead to minors in Computer Applications, Economics, Business, Wildlife (expandable to give Wildlife Biologist certification by the Wildlife Society), Parks and Wilderness, Environmental Studies, Wood Products or Forest Science. BScFE graduates are qualified to deal with engineering, implementation, and production aspects of management plans that are ecologically sound an economically feasible. Both programs include a Professional Experience Term. Graduate programs leading to MScF of MF degrees are available in forest soils, hydrology and meteorology, ecology, management, economics, pathology, entomology, information systems, conservation, wildlife management, tree physiology, and wood science. MScFE and MFE programs are available in environmental studies, operations management, harvesting, wood supply, site preparation and stand establishment, geotechnical engineering, roads and transportation, industrial engineering, machine design, wood products and wood engineering. $\mathrm{PhD}$ programs are available in the same fields. Enquiries should be directed to the Assistant Dean, P.O. Box 44555, E3B 6C2, or phone (506) 453-4501, E-mail: forem @ unb.ca.

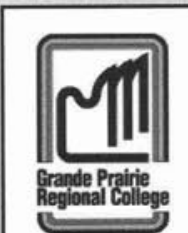

GRANDE PRAIRIE REGIONAL COLLEGE, Bachelor of Applied Forest Resource Management Program Grande Prairie, Alberta - The forest industry has indicated a hiring preference for graduates with practical experience. Our unique four-year degree program, developed in partnership with the forest industry, provides that experience. The program emphasizes applied learning through six semesters of academic course work on campus, and two semesters of practicum at an industry site. The practicum, which carries some financial assistance, covers the range of skills essential to a forestry graduate. With Grande Prairie and vicinity supporting a number of major forest industries, Grande Prairie Regional College is ideally situated to host this Applied Degree program. Upon completion of the program, you will be prepared for employment in a broad range of occupations in forestry. For further information, contact the Registrar, Grande Prairie Regional College, 10726-106 Avenue, Grande Prairie, Alberta, T8V 4C4. Phone: 1-888 539-GPRC. Website: www.gprc.ab.ca/courses_and_programs/forestry E-mail: lynn@gprc.ab.ca. 